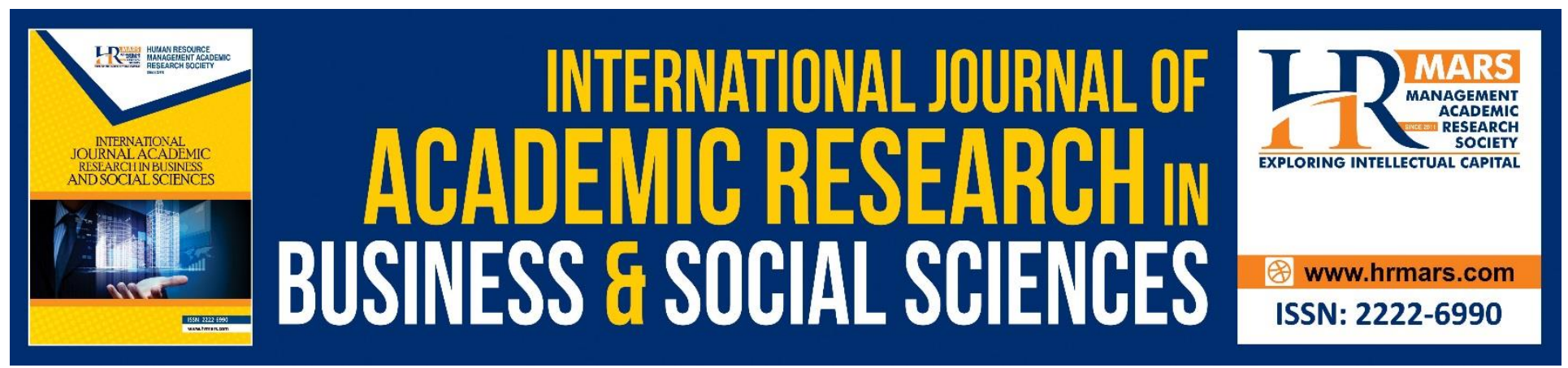

\title{
Teachers' Anxiety and Technological Pedagogical Content Knowledge (TPACK) in Mathematics
}

Wanda Nugroho Yanuarto, Siti Mistima Maat and Hazrati Husnin

To Link this Article: http://dx.doi.org/10.6007/IJARBSS/v10-i11/8115

DOI:10.6007/IJARBSS/v10-i11/8115

Received: 17 September 2020, Revised: 09 October 2020, Accepted: 29 October 2020

Published Online: 23 November 2020

In-Text Citation: (Yanuarto, Maat, and Husnin, 2020)

To Cite this Article: Yanuarto, W. N., Maat, S. M., and Husnin, H. (2020). Teachers' Anxiety and Technological Pedagogical Content Knowledge (TPACK) in Mathematics. International Journal of Academic Research in Business and Social Sciences. 10(11), 441-451.

Copyright: (C) 2020 The Author(s)

Published by Human Resource Management Academic Research Society (www.hrmars.com)

This article is published under the Creative Commons Attribution (CC BY 4.0) license. Anyone may reproduce, distribute, translate and create derivative works of this article (for both commercial and non-commercial purposes), subject to full attribution to the original publication and authors. The full terms of this license may be seen

at: http://creativecommons.org/licences/by/4.0/legalcode

Vol. 10, No. 11, 2020, Pg. 441 - 451

http://hrmars.com/index.php/pages/detail/IJARBSS

JOURNAL HOMEPAGE

Full Terms \& Conditions of access and use can be found at http://hrmars.com/index.php/pages/detail/publication-ethics 


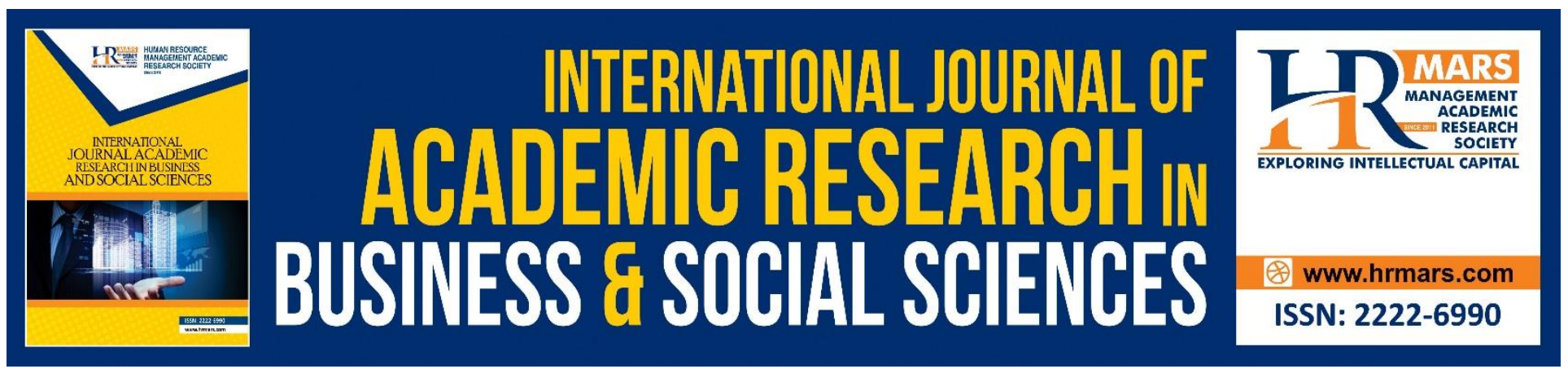

\title{
Teachers' Anxiety and Technological Pedagogical Content Knowledge (TPACK) in Mathematics
}

\author{
Wanda Nugroho Yanuarto, Siti Mistima Maat and Hazrati Husnin \\ Center of Teaching and Learning Innovations, Faculty of Education, Universiti Kebangsaan \\ Malaysia, Bangi, Malaysia \\ Email: P92896@siswa.ukm.edu.my, sitimistima@ukm.edu.my, hazrati@ukm.edu.my
}

\begin{abstract}
Mathematics anxiety tends to be intensely concentrated and clearly reflected mathematics content knowledge, while Mathematics teaching anxiety is based on the individual's ability to teach Mathematics. Teaching in the $21^{\text {st }}$-Century era required teachers to have TPACK. TPACK is a combination of technological, pedagogical, and content knowledge. TPACK effectively understands the structure, representation, and adaptation of a topic, problem and content adapted according to the technology and abilities of teachers and presented in teaching. This study aims to: 1) describe the aspects of teachers' anxiety; 2) picture the sub-construct of TPACK; and 3) describe the relationship between teachers' anxiety and TPACK in Mathematics based on documents analysis. Studies assess that mathematics anxiety does not have a significant influence on the teachers' content knowledge. Also, mathematics teaching anxiety and pedagogical expertise have a meaningful relationship. Outstanding teaching can provide a good understanding of Mathematics with pedagogical knowledge. As well, a positive attitude towards TPACK is an indicator of knowledge that can influence mathematics anxiety. Teachers who demonstrate knowledge and a positive attitude towards mathematics will show better potential to hypotheses and build instructional design. It has a positive effect on teaching Mathematics.
\end{abstract}

Keywords: Teachers' Anxiety, Mathematical Content Knowledge, Pedagogical Knowledge, Technological Knowledge.

\section{Introduction}

Several studies investigated the relationship of mathematics anxiety and teaching mathematics anxiety to technological knowledge (Gnanamuthu \& Krishnakumar, 2015; Jackson, 2017). The primary approach is to determine how mathematics anxiety can affect technological knowledge (TK). It suggested in the research on the relationship between mathematics anxiety and TK (Afshari et al., 2019). Mathematics Anxiety Rating Scale-Short Version (MARS-SV) was developed by Suinn and Winston (2003) to measure teacher Mathematics anxiety. Teachers who do not have technological pedagogical knowledge are not able to use online application shielding for Mathematics teaching. Some of the mathematics application teaching that teachers use in the classroom are GeoGebra, 
INTERNATIONAL JOURNAL OF ACADEMIC RESEARCH IN BUSINESS AND SOCIAL SCIENCES Vol. 10, No. 11, 2020, E-ISSN: 2222-6990 @ 2020 HRMARS

Cabri, and mathematical laboratory (MathLab). It presents by Smaldino (2011), he also argues that Mathematics application should also not be used by teachers who consider its use to bring anxiety teaching Mathematics in the classroom.

Various studies provide an overview of the concerns of the Mathematics anxiety towards TPACK. Studies are evaluating that Mathematics anxiety does not have a significant influence on content knowledge (Jackson, 2017). Teachers who are proficient in using Mathematics content in the classroom feel enough to teach Mathematics as they usually do. Another reason says that the availability of applicable technology will change the purpose of teaching Mathematics itself (Awofala et al., 2017). Mathematics anxiety is closely related to low skills in understanding the concepts of Mathematics (Drijvers et al., 2015; Kafyulilo et al., 2015).

Some other studies aim to teach mathematics using some of the technology software, in line with technology in today's world of education (Smaldino, 2011) and providing teacher assistance in the construction of Mathematics in the classroom by Mathematics technology. Some applicable Mathematics lessons refer to technological pedagogical knowledge in the school, such as flipped classroom teaching and many more. However, it is not possible when teachers experienced anxiety and have low TPACK skills (Yanuarto, 2016).

This study aims to: 1) describe the aspects of teachers' anxiety; 2) picture the sub-construct of TPACK; and 3) describe the relationship between teachers' anxiety and TPACK in Mathematics based on documents analysis. Besides, the teaching of Mathematics anxiety and pedagogical knowledge has a significant relationship. Outstanding teaching can provide a good understanding of Mathematics with pedagogical knowledge (Faozieh and Pourhosein, 2018). Another case reveals that Mathematics teachers with common pedagogical knowledge (PK) have significant concerns about teaching in the classroom (Sivakova et al., 2017). Based on the study, it found that Mathematics teaching anxiety has a positive relationship to technological pedagogical knowledge (Drijvers et al., 2015; Kafyulilo et al., 2015) while Mathematical anxiety has no positive connection to content knowledge (Jackson, 2017; Awofala, 2017).

\section{Teachers' Anxiety in Mathematics}

Studies from various affective variables related to Mathematics education revealed that mathematics anxiety had become the most actively sought (Boyd et al., 2014; Matoti \& Lekhu, 2016; Novak \& Tassell, 2017; Ramirez et al., 2018). Mathematics anxiety is a complex construct and has been defined in a variety of ways. Uysal and Dede (2016) describe mathematics anxiety as a state of discomfort in response to situations involving Mathematical activities considered self-threatening and self-esteem.

The study of mathematics anxiety is contradictory. However, some researchers consider Mathematics anxiety as an affective variable in addition to the formation of technological, content, and pedagogical knowledge (Haciomeroglu, 2018). Gnanamuthu and Krishnakumar (2015) investigate Mathematics concerns in primary school teachers. In their study, gender and educational qualifications were contributing to mathematics anxiety. Other researchers represent mathematics anxiety as a sub-construction of attitudes towards Mathematics (Jong \& Hodges, 2015). In Haciomeroglu's (2013) study on Mathematics anxiety of teacher candidates, he referred to the perspective of Mathematics as construction of various aspects that include Mathematics anxiety and teaching Mathematics anxiety. In fact, in educational research, mathematics anxiety is often 
INTERNATIONAL JOURNAL OF ACADEMIC RESEARCH IN BUSINESS AND SOCIAL SCIENCES Vol. 10, No. 11, 2020, E-ISSN: 2222-6990 @ 2020 HRMARS

combined with broader issues, attitudes towards Mathematics, and attitudes toward teaching Mathematics in the classroom (Haciomeroglu, 2018; Uysal \& Dede, 2016).

Also, to develop a comprehensive understanding of teachers' concerns, it is necessary to explore research that examines their anxiety factors. Gender factors are considered a cause for concern. Many studies stated that men have a more substantial Mathematical background (Gnanamuthu \& Krishnakumar, 2015). Therefore, women who take Mathematics courses are considered weaker than male students. This weakness is deemed to cause Mathematics anxiety. According to Puteh (2016), women often change their educational careers if Mathematics plays a significant role in course selection. Moreover, in general, researchers agree that more research is needed for Mathematics anxiety in cognitive activities to analyze both affective and cognitive components (Leary, Fitzpatrick, \& Hallett, 2017). In contrast, the cause of teaching mathematics anxiety is seen in affective activities to analyze cognitive and affective components (Novak \& Tassell, 2017).

While the findings found that primary school teachers with high teaching Mathematics anxiety tend to encourage dependence, such as teachers as the primary source of information (Alkan, 2013), teaching Mathematics anxiety often uses its teaching statically and does not use teaching innovations such as models of Mathematics in their education (Leary et al., 2017). However, effective teaching of Mathematics for students is usually taught by teachers who have low teaching mathematics anxiety (Mji and Arigbabu, 2012).

According to Filippatou et al. (2016), teaching mathematics anxiety is based on the ability of individuals to teach Mathematics. Simultaneously, Mathematics anxiety tends to be intensely focused and reflects a lack of mathematics content knowledge. Also, teaching mathematics anxiety focuses on externally and reflects teachers engage students in teaching Mathematics (Moustafa, Tindle, Ansari, Doyle, \& Hewedi, 2017). Similarly, Leary et al. (2017), teachers who have low mathematics anxiety will also have intense teaching mathematics anxiety. Therefore, this decision has important implications for teachers, not only for teachers who are experiencing mathematics anxiety but also support teachers who have teaching mathematics anxiety.

\section{TPACK in Mathematics}

With the emergence of technology in daily life and education in the current era of technology, we have begun to address the impact of teachers' technology knowledge. While some researchers have started to see the crossroads of pedagogy and technology in the development of non-content specific knowledge domains such as technological pedagogical knowledge (Maesuri et al. 2016), others have examined the crossroads of pedagogy and technology in the development of TPACK (Koehler et al., 2014).

TPACK introduced by Koehler et al. (2014) and today is still being studied and gives different concepts among researchers. The study of TPACK is conducted in various forms of approach and viewed from multiple perspectives (Rahmany, Sadeghi, \& Chegini, 2017). Kleickmann et al. (2013) identified the components of TPACK in mathematics as a priority for teachers, pedagogy for teaching, the use of technology in education, and content in mathematics.

TPACK is a combination of technological knowledge, pedagogical knowledge, and content knowledge. TPACK is useful in understanding the structure, representation, and adaptation of a topic. Besides, TPACK is adapted according to the interests, technology, and abilities of teachers and presented in teaching (Koehler et al., 2014). Pedagogical content knowledge (PCK) refers to concepts, 
INTERNATIONAL JOURNAL OF ACADEMIC RESEARCH IN BUSINESS AND SOCIAL SCIENCES Vol. 10, No. 11, 2020, E-ISSN: 2222-6990 @ 2020 HRMARS

procedures, misconceptions, types of understandings, mastery assessment techniques, and conceptual understanding (Aoibhinn, 2016). Meanwhile, the effectiveness of teaching Mathematics requires the skills to provide continuous and varied training, enrichment activities, classroom management, evaluate Mathematics materials, and curriculum (Dapaepe, Verschaffel, \& Kelchtermans, 2013).

According to the constructivist view, technological content knowledge (TCK) is actively construct by teachers and students (Sonia, 2016). To understand how PCK incorporated into technology, teachers must-have components of pedagogical technology concepts (Aoibhinn, 2016). The use of technology software is part of technological knowledge (TK) in the teaching of Mathematics, such as Inquisit 4 Web OSAN (Durdu \& Dag, 2017). The technology allows teachers to complete tasks independently from testing and calculating their scores and the various time required to solve Mathematics problems.

PCK introduce by Shulman (1986). Through the model Shulman (1986), to provide effective teaching, teachers need to be an expert. In other words, teachers need to know what to teach and how to teach. Therefore, Shulman (1986) stressed that teachers need to master two components of knowledge; content knowledge (CK) and pedagogical knowledge (PK). CK refers to the understanding of the curriculum, content, and learning outcomes of a subject. Meanwhile, PK is related to approaches and techniques to convey the content of the issue. Previous studies have demonstrated the need for teachers to have CK and PK in ensuring effective teaching (Booker, 2017; Dapaepe et al., 2013).

While technological content knowledge (TCK) refers to the ability of teachers to make connections between the topics of Mathematics to technology (Fu, 2019), TCK is also a category used to differentiate the understanding characteristics of a Mathematical content expert from a technology expert (Yigit, 2014). Teachers with good TCK can produce productive questions in the classroom (Valtonen et al., 2019). TCK is practical knowledge for teaching by combining content and technology. TCK includes effective technology planning procedures, practices in Mathematics classrooms, classroom management techniques, and variations in mathematics technology (Kim 2018).

Meanwhile, technological pedagogical knowledge (TPK) is one aspect of TPACK. TPK encompasses curriculum knowledge, including the selection and use of appropriate materials for use in the curriculum. Also, TPK refers to knowing how teachers think, teaching technology preparation, and mastering all forms of teaching technology delivery methods. TPK represents technological formulations that applied in teaching (Galleto, 2018). TPK must contain teachers' pedagogy knowledge, classroom teaching strategies, effective use of technology, and technological understanding (Malubay \& Daguplo, 2018).

\section{Teachers' Anxiety and TPACK in Mathematics}

Booker (2017) conducted a mixed-method study to investigate the relationship of TPACK in the use of their technology in schools with the concerns they have. He found that teachers are rich in TPACK and had low mathematics anxiety was used to prepare lessons and for student-centered teaching. It may be consistent with Dogan (2012) description that TPACK is closely related to anxiety. Teachers should have good CK and the content of the Mathematics curriculum to implement teaching strategies in the classroom. But, the challenge of education in the current era by using technology can control the concerns of teachers. A study from Palak and Walls (2009) found that the use of 
INTERNATIONAL JOURNAL OF ACADEMIC RESEARCH IN BUSINESS AND SOCIAL SCIENCES Vol. 10, No. 11, 2020, E-ISSN: 2222-6990 @ 2020 HRMARS

technology for teachers to support teaching using technology even though some teachers have low teaching anxiety. So, it affects that there is a relationship between TPACK and the concerns of teachers' anxiety.

Although the review of the study found that many barriers to TPACK in the use of Mathematics teaching technology do not have a good effect on teachers' anxiety, but a survey from Judson (2014) explores the close relationship between TPACK, especially in teaching mathematics anxiety. Moreover, other studies explain that TPACK systems have the most significant impact on teaching mathematics anxiety (Bick-har, 2016). Similarly, teachers combining teaching and technological innovation are highly dependent on the low anxiety of their education (Eickelmann \& Vennemann 2017).

According to Voogt et al. (2020) a positive attitude towards TPACK is an indicator of the knowledge that can influence anxiety. The teachers who have a positive attitude towards knowledge and low anxiety will show better potential to build instructional design. Also, it has a positive effect on the right attitude towards Mathematics. Wilson (2018) positive thinking and feelings towards Mathematics will have a positive impact on Mathematical knowledge, teaching based on TPACK, and promoting technology in the classroom. This attitude will undoubtedly reduce the anxiety of Mathematics in teachers. In general, a positive attitude towards TPACK tends to encourage teachers to implement three basic processes of knowledge; Mathematical content, pedagogy, and technology (Fu 2019). Thus, TPACK has a positive effect on reducing teachers' anxiety.

Investigations into TPACK of Mathematics anxiety are not always permanent. As can be obtained from the study of Papanikolaou et al. (2017), the relationship between TPACK with the concerns of secondary school Mathematics teachers' anxiety in Japan is not significant. It means that the higher education background of Mathematics teachers does not give a picture of teachers' anxiety. The teaching of Mathematics in Japan emphasizes the use of technology over traditional instruction. Teaching does not depend on the high level of teachers' education and the level of anxiety. Other research results show that contradicted, Carrillo et al. (2018), working around the teaching of Mathematics is generated from using technology in the classroom. The learning of Mathematics using technology encourages teachers to learn how to use Mathematical research and TPACK. They accept changes in teachers' attitudes towards Mathematics and the low level of teachers' anxiety produced.

Furthermore, the findings of the study from the relationship of TPACK with anxiety in Indonesia and Malaysia, as investigated by Yuniarti and Pang (2014) say that Mathematics teachers who have a low level of anxiety will apply teaching based on constructivism. This teaching will be better when the teacher has better TPACK. Their results found that teachers with a high level of TPACK are more open in providing any questions and opportunities for students to ask about the goals of Mathematics content in the classroom.

\section{Conclusion}

Studies assess that mathematics anxiety does not have a significant relationship with TPACK issues. Teachers who use mathematics content feel it is enough to teach Mathematics as they usually do. Another reason to say that the availability of applicable technology will change the purpose of teaching Mathematics itself. Also, Teaching mathematics anxiety and TPACK have a significant relationship. Outstanding teaching can provide a good understanding of Mathematics with TPACK. They were providing goals for the effective teaching of Mathematics using some of the advanced 
INTERNATIONAL JOURNAL OF ACADEMIC RESEARCH IN BUSINESS AND SOCIAL SCIENCES Vol. 10, No. 11, 2020, E-ISSN: 2222-6990 @ 2020 HRMARS

technologies. Therefore, the role of technology useful for use in face to face teaching or online learning. However, the advanced technology used in the classroom is not possible when teachers have low TPACK performance and experienced teaching mathematics anxiety. Thus, a positive attitude towards TPACK is an indicator of knowledge that can influence teachers' anxiety. It has a positive effect on thinking and feeling towards Mathematics.

\section{Acknowledgment}

We would like to thank our reviewers for the constructive comment and feedback. To our family members, colleagues, thank you in advance for the warmly support to us.

\section{Corresponding Author}

Wanda Nugroho Yanuarto

Faculty of Education, Universiti Kebangsaan Malaysia, Bangi, Malaysia

Email: P92896@siswa.ukm.edu.my

\section{References}

Afshari, M., Bakar, K. A., Luan, W. S., Samah, B. A., \& Fooi, F. S. (2019). Factors affecting teachers' use of Information \& communication technology. International Journal of Instruction, 2(1), 77-104. https://doi.org/10.1080/14759390000200096

Alkan, V. (2013). Reducing Mathematics Anxiety: The ways implemented by teachers at primary schools. International Journal of Social Science \& Education, 3(3), 795-807.

Aoibhinn, N. S. (2016). Developing mathematics teachers' pedagogical content knowledge in lesson study. International Journal for Lesson and Learning Studies, 5(3), 212-226.

Aslan, D., Ogul, I. G., \& Tas, I. (2013). The impacts of preschool teachers' mathematics anxiety and beliefs on mathematics achievement. International Journal of Humanities and Social Science Invention, 2(7), 45-49.

Beilock, S. L., Gunderson, E. A., Ramirez, G., \& Levine, S. C. (2010). Female teachers' math anxiety affects girls' math achievement. Proceedings of the National Academy of Sciences, 107(5), 1860-1863. https://doi.org/10.1073/pnas.0910967107

Bick-har, L. (2016). The relationship between conceptions of teaching and approaches to teaching. Teachers and Teaching,12(December), 693-713. https://doi.org/10.1080/13540600601029744

Booker, S. (2017). The evolution of pre-service teachers TPACK after completing an undergraduate technology integration course. Journal of Educational Research, 3(1), 332-346.

Boyd, W., Foster, A., Smith, J., \& Boyd, W. E. (2014). Feeling good about teaching mathematics: Addressing anxiety amongst pre-service teachers. Creative Education, 5(4), 207-217. https://doi.org/10.4236/ce.2014.54030

Carpenter, T. P., Fennema, E., Peterson, P. L., Chiang, C.-P., \& Loef, M. (1989). Using knowledge of children's mathematics thinking in classroom teaching: An Experimental Study. American Educational Research Journal, 26(4), 499-531. https://doi.org/10.3102/00028312026004499

Carrillo, J., Climent, N., \& Contreras, L. C. (2018). Determining specialised knowledge for mathematics teaching. Journal of Educational Technology Development and Exchange, 3(2), 1-10. 
INTERNATIONAL JOURNAL OF ACADEMIC RESEARCH IN BUSINESS AND SOCIAL SCIENCES Vol. 10, No. 11, 2020, E-ISSN: 2222-6990 @ 2020 HRMARS

Dapaepe, F., Verschaffel, L., \& Kelchtermans, G. (2013). Pedagogical content knowledge: A systmatic review of the wya in which the concept has pervaded mathematics educaitonal research. Teaching and Teacher Education, 34, 12-25. https://doi.org/10.1016/j.tate.2013.03.001

Deemer, S. (2010). revealing links between teacher beliefs and classroom environments Classroom goal orientation in high school classrooms. Educational Research, 46(June 2013), 37-41. https://doi.org/10.1080/0013188042000178836

Destiana, B. (2013). Faktor determinan pemanfaatan TIK dan pengaruhnya terhadap kinerja Guru SMK di Kabupaten Gunungkidul. Jurnal Pendidikan Vokasi, (1), 285-299.

Dogan, M. (2012). Prospective Turkish primary teachers' views about the use of computers in mathematics education. Journal of Mathematics Teacher Education, 15(4), 329-341. https://doi.org/10.1007/s10857-012-9214-3

Drijvers, P. H. M., Monaghan, J., Thomas, M., \& Trouche, L. (2017). Use of technology in secondary mathematics. Journal for Research in Mathematics Education, 4(3), 14-23. Retrieved from http://dspace.library.uu.nl/handle/1874/315455

Durdu, L., \& Dag, F. (2017). Pre-service teachers' TPACK development and conceptions through a TPACK-Based Course. Australian Journal of Education, 42(11), 150-174.

Eickelmann, B., \& Vennemann, M. (2017). Teachers' attitudes and beliefs regarding ICT in teaching and learning in European countries. European Educational Research Journal, 16(6), 733-761. https://doi.org/10.1177/1474904117725899

Fang, Z., \& Building, E. (2006). A review of research on teacher beliefs and practices. Educational Research, 38(July 2013), 37-41. https://doi.org/10.1080/0013188960380104

Faozieh, S., \& Pourhosein, A. G. (2018). Teachers' attitudes about computer technology training, Professional Development, Integration, Experience, Anxiety, and Literacy in English Language Teaching and Learning. International Journal of Applied Science and Technology, 3(1), 67-75. Retrieved from www.ijastnet.com

Filippatou, D., Pantazi, E., \& Triandafillidis, T. (2016). Math anxiety and achievement in mathematics. Proceedings of ICERI, (November), 2138-2147. https://doi.org/10.21125/iceri.2016.1482

$\mathrm{Fu}$, J. S. (2019). TPACK in education: A critical literature review and its implications. International Journal of Education and Development Using Information and Communication Technology, 9(1), 112. https://doi.org/http://ijedict.dec.uwi.edu//viewarticle.php?id=1541

Galleto, P. G. (2018). Diagnosing technological pedagogical content knowledge landscape: The Case of the mathematics teachers in government-funded. International Journal of Scientific Research and Education, 6(7), 7994-8002. https://doi.org/10.18535/ijsre/v6i7.03

Gnanamuthu, J. S., \& Krishnakumar, R. (2015). Anxiety of B. Ed. teacher trainees' towards ICT. Journal of Education Learning, 1(6), 59-62.

Gurcay, D., Wong, B., \& Chai, C. S. (2018). Turkish and Singaporean pre-service teachers' beliefs about ICT literacy and use of technology. Asia-Pacific Education Researcher, 22(2), 155-162. https://doi.org/10.1007/s40299-012-0008-2

Haciomeroglu, G. (2018). Mathematics anxiety and mathmatics beliefs: What is the relationship in elemantary pre-service teacher? Issues in The Undergraduate Mathematics Preparation of School Teachers, 5(February), 1-9.

Yanuarto, W. N. (2017). Flipped classroom: From practice to technologies. Journal for Technological Knowledge, 3(8), 36-46. 
INTERNATIONAL JOURNAL OF ACADEMIC RESEARCH IN BUSINESS AND SOCIAL SCIENCES

Vol. 10, No. 11, 2020, E-ISSN: 2222-6990 @ 2020 HRMARS

Jackson, M. (2017). Integration of ICT in the mathematics classroom. Journal of Initial Teacher Inquiry, 3(1), 90-93.

Jong, C., \& Hodges, T. E. (2015). Assessing attitudes toward mathematics across teacher education contexts. Journal of Mathematics Teacher Education, 18(5), 407-425. https://doi.org/10.1007/s10857-015-9319-6

Judson, E. (2014). How teachers integrate technology and their beliefs about learning: Is there a connection? Journal of Information Technology for Teacher Education, 14(May), 581-597.

Kafyulilo, A., Fisser, P., \& Pieters, J. (2018). ICT use in science and mathematics teacher education in Tanzania: Developing technological pedagogical content knowledge. Journal of Education for Teaching, 31(4), 381-399.

Keong, C. C., Horani, S., \& Daniel, J. (2018). A study on the use of ICT in mathematics teaching. Malaysian Online Journal of Instructional Technology (MOJIT), 2(January 2018), 43-51.

Kim, S. (2018). Technological pedagogical and content knowledge ( TPACK ) and beliefs of preservice secondary mathematics teachers: Examining the relationships. EURASIA Journal of Mathematics, Science \& Technology Education, 14(10), 1-24.

Kleickmann, T., Richter, D., Kunter, M., Elsner, J., Besser, M., Krauss, S., \& Baumert, J. (2013). Teachers' content knowledge and pedagogical content knowledge: The role of structural differences in teacher education. Journal of Teacher Education, 64(1), 90-106. https://doi.org/10.1177/0022487112460398

Koehler, M. J., Mishra, P., Kereluik, K., Shin, T. S., \& Graham, C. R. (2014). The technological pedagogical content knowledge framework. In Handbook of Research on Educational Communications and Technology (pp. 101-111). https://doi.org/10.1007/978-1-4614-3185-5

Leary, K. O., Fitzpatrick, C. L., \& Hallett, D. (2017). Math anxiety Is related to Some, but Not All, Experiences with Math. Original Research, 8(December), 1-14. https://doi.org/10.3389/fpsyg.2017.02067

Luke, A., \& Freebody, P. (1999). Further notes on the four resources model. Reading Online, 8. Retrieved from papers://8823b2b3-0f26-4eac-b58e-76a95997f0e0/Paper/p122

Maesuri, S., Tom, P., \& Barney, L. (2016). Analysing mathematics teachers' TPACK through observation of practice. The Asia-Pacific Education Researcher, 12(1), 1-10. https://doi.org/10.1007/s40299-016-0305-2

Malubay, J., \& Daguplo, M. S. (2018). Characterizing mathematics teachers' technological pedagogical content knowledge. European Journal of Education Studies, 4(1), 199-219. https://doi.org/10.5281/zenodo.1160586

Matoti, S. N., \& Lekhu, M. A. (2016). Sources of anxiety among pre-service teachers on field placement experience. Journal of Psychology in Africa, 26(3), 304-307. https://doi.org/10.1080/14330237.2016.1185921

Mji, A., \& Arigbabu, A. A. (2012). Relationships between and among pre-service mathematics teachers' conceptions, efficacy beliefs and anxiety. Journal of Education Beliefs, 4(3), 261-270.

Moustafa, A. A., Tindle, R., Ansari, Z., Doyle, M. J., \& Hewedi, D. H. (2017). Mathematics, anxiety, and the brain. Review of Educational Research, (June 2018), 1-14. https://doi.org/10.1515/revneuro-2016-0065

Novak, E., \& Tassell, J. L. (2017). Studying preservice teacher math anxiety and mathematics performance in geometry, word, and non-word problem solving. Learning and Individual Differences, 54, 20-29. https://doi.org/10.1016/j.lindif.2017.01.005 
INTERNATIONAL JOURNAL OF ACADEMIC RESEARCH IN BUSINESS AND SOCIAL SCIENCES Vol. 10, No. 11, 2020, E-ISSN: 2222-6990 @ 2020 HRMARS

Palak, D., \& Walls, R. T. (2009). Teachers' beliefs and technology practices: A mixed-methods approach. Journal of Research on Technology in Education, 41(4), 417-441. https://doi.org/10.1080/15391523.2009.10782537

Papanikolaou, K., Makri, K., \& Roussos, P. (2017). Learning design as a vehicle for developing TPACK in blended teacher training on technology enhanced learning. International Journal of Education and Research, 2(13), 1-14. https://doi.org/10.1186/s41239-017-0072-z

Peterson, P. L., Fennema, E., Caroenter, T. P., \& Loef, M. (1989). Peterson. Cognition and Instruction, 6(April), 40. https://doi.org/10.1207/s1532690xci0601

Puteh, M. (2016). Effective teaching: Pedagogical content knowledge. Proceeding of International Joint Seminar Garut, (June), 1-9.

Rahmany, R., Sadeghi, B., \& Chegini, A. S. (2017). Normalization of CALL and TPACK: Discovering teachers' opportunities and challenges. Journal of Language Teaching and Research, 6(2), 891900. https://doi.org/10.4304/jltr.5.4.891-900

Ramirez, G., Hooper, S. Y., Kersting, N. B., Ferguson, R., \& Yeager, D. (2018). Teacher math anxiety relates to adolescent students' math achievement. AERA Open, 4(1), 233285841875605. https://doi.org/10.1177/2332858418756052

Schmidt, D. A., Thompson, A. D., Koehler, M. J., \& Shin, T. S. (2009). Technological pedagogical content knowledge (TPACK): The development and validation of an assessment instrument for preservice teachers. Journal of Research on Technology in Education, 42(2), 123-149.

Shulman, L. E. E. S. (1986). Those who understand: Knowledge growth in teaching. Educational Researcher, 15(2), 4-14.

Smaldino, S. E. (2011). Preparing students with $21^{\text {st }}$-Century ICT literacy in math and science education. Journal of Curriculum and Instruction, 5(1), 1-3. https://doi.org/10.3776/joci.2011.v5n1p1-3

Sonia, G. (2016). Teachers' pedagogical knowledge and the teaching profession. Journal of Educational Research, 3(1), 221-235.

Suinn, R. M., \& Winston, E. H. (2003). (2003). The mathematics anxiety rating scale, Journal of Mathematical Knowledge, 3(1), 167-173.

Tobias, S., \& Weissbrod, C. (1980). Anxiety and mathematics: An update. Harvard Educational Review, 50(1), 63-70. https://doi.org/10.17763/haer.50.1.xw483257j6035084

Uysal, F., \& Dede, Y. (2016). Mathematics anxiety and beliefs of Turkish pre-service elementary teachers. EURASIA Journal of Mathematics, Science \& Technology Education, 12(8), 2171-2186. https://doi.org/10.12973/eurasia.2016.1418a

Valtonen, T., Sointu, E., Kukkonen, J., Kontkanen, S., Lambert, M. C., \& Makitalo-siegl, K. (2019). TPACK updated to measure teachers' twenty-first century skills. Austalasian Journal of Educational Technology, 33(3), 15-31.

Wilson, D. (2018). Investigating pre-service teachers' mathematics anxiety towards TPACK in classroom. Journal for Research in Mathematics Education, 3(20), 442-451. Retrieved from http://www.merga.net.au/publications/counter.php?pub=pub_conf\&id=2028

Yanuarto, W. (2016). Teachers awareness of students' anxiety in math classroom: Teachers' treatment vs students' anxiety. Journal of Education and Learning (EduLearn), 10, 235-243. Retrieved from http://www.journal.uad.ac.id/index.php/EduLearn/article/view/3808 
INTERNATIONAL JOURNAL OF ACADEMIC RESEARCH IN BUSINESS AND SOCIAL SCIENCES

Vol. 10, No. 11, 2020, E-ISSN: 2222-6990 @ 2020 HRMARS

Yigit, M. (2014). A Review of the literature: How pre-service mathematics teachers develop their technological, pedagogical, and content knowledge. International Journal of Education in Mathematics, Science and Technology, 2(1), 26-35.

Yuniarti, S., \& Pang, V. (2014). The relationship between mathematical beliefs and mathematics anxiety among pre-service elementary school teachers in East Borneo, Indonesia. Journal of Education and Learning, 3(1), 237-243. 